\title{
IDH Family Wildtype
}

National Cancer Institute

\section{Source}

National Cancer Institute. IDH Family Wildtype. NCI Thesaurus. Code C136567.

A genetic finding indicating that no nucleotide sequence change has been detected in any IDH family gene. 